\title{
Study on ESI-based Marine Oil Spill Emergency Response Decision Support
}

\author{
Rongchang Chen ${ }^{1 *}$, Jing Shi ${ }^{1}$ and Chen Liu $^{2}$ \\ ${ }^{1}$ China Waterborne Transport Research Institute, Beijing, 100088, P.R. China \\ ${ }^{2}$ Shuikeyunda Transportation Technology Development (Beijing) Co., Ltd., Beijing 100088, P.R. China \\ ${ }^{*}$ Corresponding author
}

\begin{abstract}
On the basis of field coastline investigation and highresolution satellite images, an ESI database was established for Dapeng Bay and shorelines around it in Shenzhen by applying the Marine Oil-spill Emergency Response Decision Support and Dispatch Command System in this paper. An oil-spill shoreline emergency cleanup decision support process was developed and cases were studied in this paper, and functions of the system such as forecast \& warning, sensitive resources and emergency resources management were applied to intelligently generate countermeasures for ESI-based shoreline sensitive resource emergency response.
\end{abstract}

Keywords-component; oil spill; shoreline; ESI; decision support

\section{INTRODUCTION}

In 1976, Michel et al.[1], in the research on Cook Inlet, came up with the concepts of coastal environmental graphs and classification of coastlines by relative sensitivity. Since then, shoreline classification has been gradually refined to cover some shoreline types in the North, Central and East America. At present, NOAA has integrated both static and real-time data in its Environmental Response Management Application (ERMA)[2], including information about shoreline ESI map, vessel locations, weather conditions and currents etc. to provide an integrated and easy-to-use platform for staff involved environmental emergency response and decision makers. In the NOAA's website, the public may download the shoreline ESI atlas. Ever since 1989, the geographic information system (GIS) has begun to be used in preparation and management of the ESI atlas of U.S.A., as a result, it is become easier for the information management, updating and transmission. The shoreline ESI atlas has been widely used in U.S.A.

In 90s, China begun to introduce the shoreline ESI map, for example, Chen Rongchang, et al.[3] developed the Jiaozhou Bay shoreline ESI and then integrated it into the oil spill emergency response system; Li Yun, et al.[4] used GIS to establish the environmental sensitivity map containing ESI, which has become an important part of the oil-spill contingency plan in Zhuhai Port. In general, ESI has not seen widely application in China.

In any oil-spill incident, there is a great possibility for the floating oil to directly pollute the shoreline, and the pollution of coastal environment is relatively high risk. Because the pollution consequence of spilled oil and method of clean-up depend on the shoreline type, the shoreline ESI map plays an important role in oil spill emergency response.

\section{ESTABLISHMENT OF ESIMAP}

\section{A. Environmental Sensitivity Map and ESI}

The shoreline Environmental Sensitivity Index (ESI) is a sensitivity index developed by Hazardous Materials Response Division, Office of Response and Restoration, NOAA. NOAA set up the oil-spill emergency response sensitivity maps for the coastal regions and Great Lakes in USA. The first ESI graph was produced just a few days before the incident of oil-leaking from the well "IXTOC 1" in the Gulf of Mexico in 1979[5]. From then on, ESI map has become an integral part of the oilspill contingency plan and emergency response in U.S.A., and the atlas of ESI, has covered most of American coastlines including those in Alaska and Great Lakes. Generally speaking, an ESI map contains three types of information:

Shoreline type: An index to classify shoreline's environmental sensitivity as per some certain criteria on the basis of the sensitivity of shoreline to oil, the oil retention characteristic and the difficulty in oil cleaning up.

Biological resources: Include animals, rare plants and habitats sensitive to oil, for example, submerged vegetation and coral reef.

Resources for human activities: specific areas with additional sensitivity and value due to human development and use, for example, beaches, parks, marine protected areas, water intakes and cultural relics etc.

In principle, shorelines, in terms of environmental sensitivity, are divided into ten types on the basis of ESI, i.e. from ESI 1 to ESI 10, where the higher an ESI is, the more sensitive the shoreline is, and meanwhile different ESIs represent different shoreline types, referring to Table I[5]. In addition, in the process of emergency response, shorelines with different ESIs need to be dealt with different response plans and actions. Because ESI has a complete classification system and widely used in many countries, ESI has great influence on oil spill response and become a standard to some extent. 
TABLE I. CRITERIA FOR SHORELINE ESI CLASSIFICATION

\begin{tabular}{|c|c|c|c|}
\hline ESI & Criteria & ESI & Criteria \\
\hline $1 \mathrm{~A}$ & exposed rocky coast & $8 \mathrm{~A}$ & $\begin{array}{l}\text { 1) sheltered steep scarp on } \\
\text { batholith, mud or clay } \\
\text { 2) sheltered rocky coast } \\
\text { (impermeable) }\end{array}$ \\
\hline $1 \mathrm{~B}$ & $\begin{array}{l}\text { Exposed solid man-made } \\
\text { structures }\end{array}$ & $8 B$ & $\begin{array}{l}\text { 1) sheltered solid man-made } \\
\text { structures } \\
\text { 2) sheltered rocky coast } \\
\text { (permeable) }\end{array}$ \\
\hline $1 \mathrm{C}$ & exposed rocky platform & $8 \mathrm{C}$ & sheltered riprap \\
\hline $2 \mathrm{~A}$ & $\begin{array}{l}\text { Exposed marine-erosion } \\
\text { platform on batholith, mud } \\
\text { or clay }\end{array}$ & 8D & sheltered rocky-gravel coast \\
\hline $2 \mathrm{~B}$ & $\begin{array}{l}\text { exposed steep scarp and } \\
\text { slope, clayish }\end{array}$ & $8 \mathrm{E}$ & Peat coastline \\
\hline $3 \mathrm{~A}$ & $\begin{array}{l}\text { Fine } \sim \text { medium-sized sand } \\
\text { beach }\end{array}$ & $9 \mathrm{~A}$ & sheltered intertidal zone \\
\hline 3B & $\begin{array}{l}\text { steep scarp and slope, sand- } \\
\text { beach-like }\end{array}$ & 9B & Low-vegetation coast \\
\hline $3 \mathrm{C}$ & tundra cliff & $9 \mathrm{C}$ & High-salt intertidal zone \\
\hline 4 & Coarse sand-beach & $10 \mathrm{~A}$ & seawater swamp \\
\hline 5 & $\begin{array}{l}\text { beach with mixture of sand } \\
\text { and gravel }\end{array}$ & $10 \mathrm{~B}$ & freshwater swamp \\
\hline $6 \mathrm{~A}$ & $\begin{array}{l}\text { 1) gravel beach } \\
\text { 2) gravel beach (grains and } \\
\text { cobblestones) }\end{array}$ & $10 \mathrm{C}$ & swamp \\
\hline $6 \mathrm{~B}$ & $\begin{array}{l}\text { 1) riprap } \\
\text { 2) gravel beach } \\
\text { (cobblestones and stones) }\end{array}$ & $10 \mathrm{D}$ & $\begin{array}{l}\text { 1) shrubbery wetland } \\
\text { 2) mangroves }\end{array}$ \\
\hline 7 & exposed intertidal zone & $10 \mathrm{E}$ & immersed low tundra \\
\hline
\end{tabular}

\section{B. Establishment of Shoreline ESI Map for Shenzhen Dapeng} Bay

The oil-spill emergency decision making was mainly considered in this research, focusing on the protection zones, ecologic resources, fishery resources and recreation resources etc. These resources can be divided into ecologic resource, human activities resource and shoreline resource, respectively. The shoreline investigation mainly involves original data of sensitive resources, including natural conditions as shoreline type and slope, and information about shoreline utilization and resources etc. In the shoreline investigation, both the field investigation and data collection were adopted together. In the study, the field record form, the handheld GPS, shooting and video recording were used to record information about shoreline resources. Ships and vehicles were used as transport tools for the investigation: ride vehicles to the shoreline that is accessible by road or take ships to shorelines that are farther or hardly accessible by road. Data investigation includes collecting literatures related to sensitive resources in waters of Dapeng Bay, for instance, marine protected areas, nautical charts and satellite images etc.

In this study, the Marine Oil-spill Emergency Response Decision Support and Dispatch Command System developed by China Waterborne Transport Research Institute[6] was applied to build the shoreline environment sensitive resource database which was intended to be applied in oil-spill emergency decision support. Firstly, the $0.4 \mathrm{~m}$-resolution satellite images and nautical charts were used in the study as base map to generate shoreline vector map as seen in Figure I; secondly, the shoreline was divided into 321 segments in the average length of $500 \mathrm{~m}$ and each segment was connected with the image data from field investigation; finally, on the basis of shoreline division, both the field investigation and the literature investigation were used to define attribute parameters of each segment of shoreline, including ID, description, location, length, shoreline type, shelter condition, off-shore function, onshore functions, resources, ESI, SI, PI etc. referring to Table II. In addition, an ESI-corresponding shoreline pollutant clean-up measures library was developed.

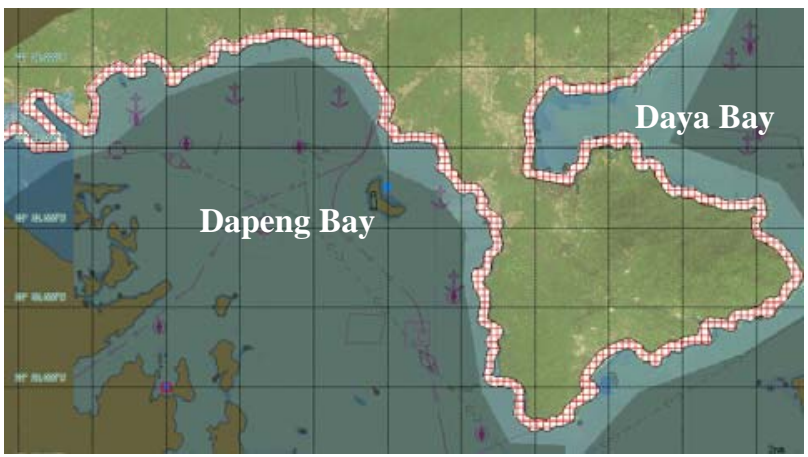

FIGURE I. SATELLITE-IMAGE-BASED SHORELINE VECTOR MAP

TABLE II. ATTRIBUTE DATA FORM OF A SINGLE SEGMENT OF SHORELINE

\begin{tabular}{|c|c|c|c|c|}
\hline $\begin{array}{l}\text { Field } \\
\text { name }\end{array}$ & ID & Description & Location & Length \\
\hline Meaning & $\begin{array}{l}\text { a unique } \\
\text { numeric code } \\
\text { corresponding } \\
\text { to a shoreline } \\
\text { segment }\end{array}$ & $\begin{array}{l}\text { Name of a } \\
\text { shoreline } \\
\text { segment }\end{array}$ & $\begin{array}{l}\text { Text } \\
\text { description } \\
\text { of the } \\
\text { geographical } \\
\text { location of a } \\
\text { shoreline } \\
\text { segment }\end{array}$ & $\begin{array}{l}\text { Length of } \\
\text { the } \\
\text { shoreline } \\
\text { segment }\end{array}$ \\
\hline $\begin{array}{l}\text { Field } \\
\text { name }\end{array}$ & $\begin{array}{c}\begin{array}{c}\text { Shoreline } \\
\text { type }\end{array} \\
\end{array}$ & $\begin{array}{c}\text { shelter } \\
\text { condition }\end{array}$ & $\begin{array}{c}\text { water } \\
\text { function }\end{array}$ & $\begin{array}{l}\text { onshore } \\
\text { function }\end{array}$ \\
\hline Meaning & $\begin{array}{l}\text { Description } \\
\text { about } \\
\text { shoreline } \\
\text { substrate, for } \\
\text { instance, sand } \\
\text { beach, riprap, } \\
\text { mangrove etc. }\end{array}$ & $\begin{array}{l}\text { Exposed, } \\
\text { sheltered or } \\
\text { half- sheltered }\end{array}$ & $\begin{array}{l}\text { Functional } \\
\text { description } \\
\text { about waters } \\
\text { around } \\
\text { shoreline }\end{array}$ & $\begin{array}{l}\text { Functional } \\
\text { description } \\
\text { about land } \\
\text { around } \\
\text { shoreline }\end{array}$ \\
\hline $\begin{array}{l}\text { Field } \\
\text { name }\end{array}$ & Resource & ESI & SI & PI \\
\hline Meaning & $\begin{array}{l}\text { Other resource } \\
\text { types, such as } \\
\text { recreational } \\
\text { area, natural } \\
\text { reserve, and } \\
\text { aquaculture } \\
\text { area etc. } \\
\text { except } \\
\text { shoreline }\end{array}$ & $\begin{array}{l}\text { Shoreline } \\
\text { environmental } \\
\text { sensitivity } \\
\text { index }\end{array}$ & $\begin{array}{l}\text { Sensitivity } \\
\text { index }\end{array}$ & $\begin{array}{l}\text { Priority } \\
\text { index of } \\
\text { protection }\end{array}$ \\
\hline
\end{tabular}

\section{APPLICATION OF ESI IN OIL-SPILL EMERGENCY DECISION SUPPORT SYSTEM}

\section{A. Oil-spill Shoreline Emergency Response Decision Process}

Some of pollutants from oil-spill incidents at near-shore waters will be driven to the coastline under the action of current and wind. For such different types of substrates as rock, 
man-made buildings, gravel, sand beach, mangrove and swamp, different measures and equipment are needed to clean up pollutants along the shoreline and in the near-shore waters. When and how pollutants reach the shoreline, as well as the range of pollution, are important in decision-making. The study provided decisions to emergently clean up spilled oil along the shoreline on the foundation of ESI database and the Marine Oil-spill Emergency Response Decision Support and Dispatch Command System, referring to Figure II for detailed decision-making process.

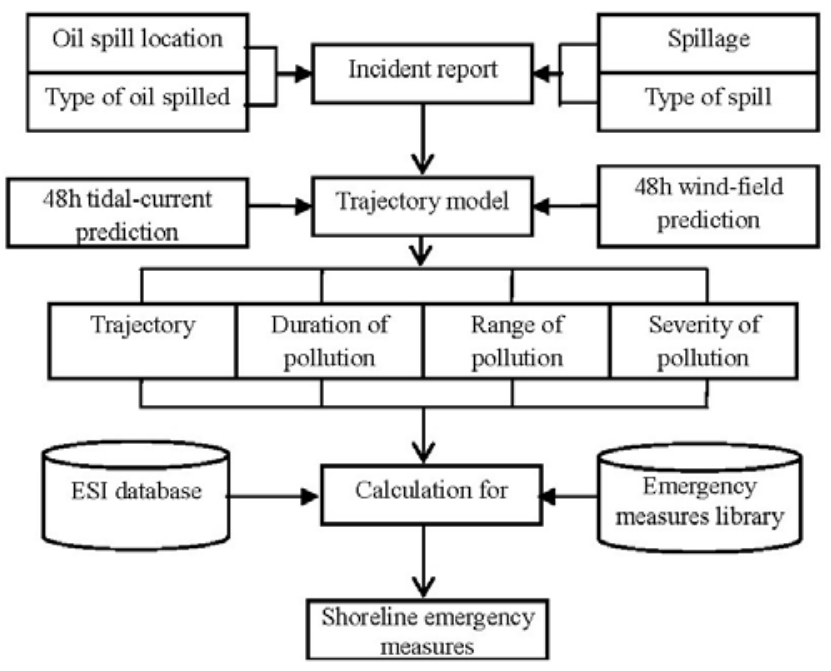

FIGURE II. OIL-SPILL SHORELINE EMERGENCY RESPONSE DECISION SUPPORT PROCESS

\section{B. Case Study}

The study assumes that a 100-ton oil-spill incident happened at the anchorage for dangerous goods in Shenzhen Dapeng Bay. See Table III for the incident scenario. The basic data for oil-spill drift and dispersion simulation forecast came from the joint wind-field and current field prediction established through the models FVCOM and WRF[7]. It is known from the result from the incident scenario trajectory forecast that after the oil spill incident happens, the spilled pollutants will be drifted and dispersed over the surface under the action of current and wind. It takes 11 hours for the pollutants to reach the shoreline after the incident occurs, and afterwards most pollutants remain absorbed to the shoreline, seeing the Figure III and Figure IV for the spilled oil drift path.

TABLE III. INCIDENT SCENARIO

\begin{tabular}{|c|c|c|}
\hline \multicolumn{2}{|c|}{ Incident parameter } & Oil-spill incident \\
\hline \multirow{4}{*}{ Incident scenario } & Duration of spill & 1 hour \\
\hline & $\begin{array}{l}\text { Type of oil } \\
\text { spilled }\end{array}$ & fuel oil \\
\hline & Spillage & $100 \mathrm{t}$ \\
\hline & Location of spill & $\begin{array}{l}\text { Anchorage for dangerous } \\
\text { goods }\end{array}$ \\
\hline \multirow{2}{*}{$\begin{array}{l}\text { Weather and sea } \\
\text { condition }\end{array}$} & $\begin{array}{l}\text { Sea-surface } \\
\text { wind }\end{array}$ & 48h wind-field prediction \\
\hline & Current field & 48h current-field prediction \\
\hline \multicolumn{2}{|c|}{ Time length of forecast } & $24 \mathrm{~h}$ \\
\hline
\end{tabular}

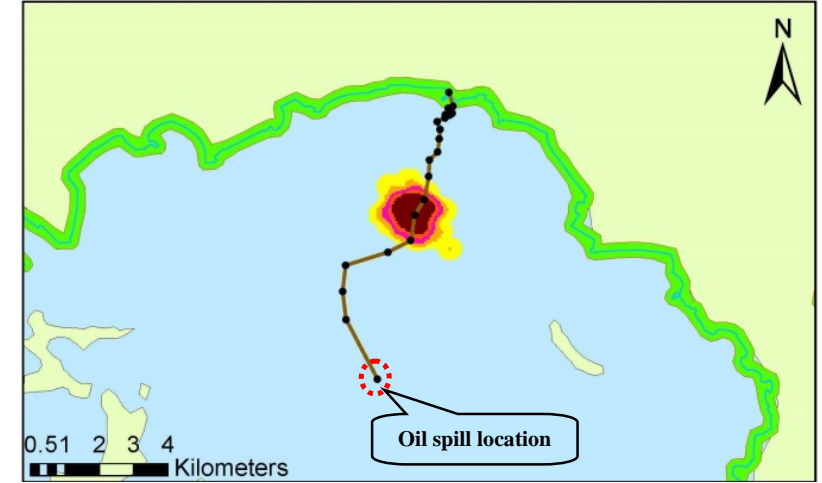

FIGURE III. OIL SPILL DRIFT PATH (6 HOURS AFTER THE INCIDENT)

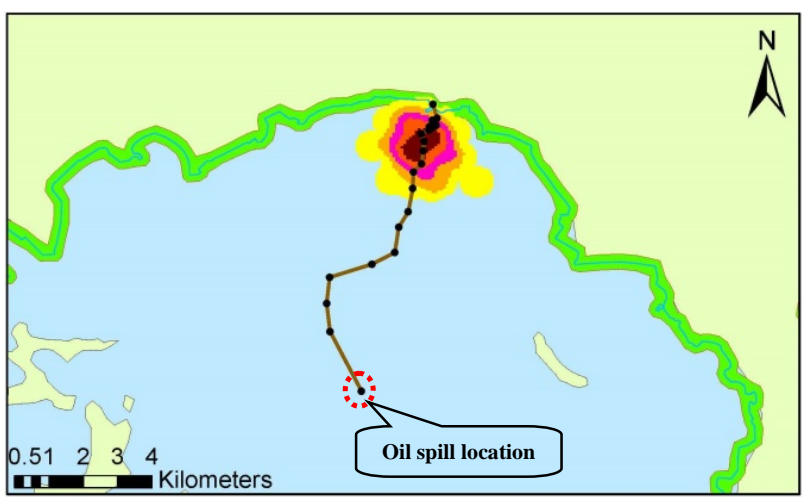

FIGURE IV. Oil spill drift path (11 hours after the incident)

According to the calculation by overlaying and coupling the drift path, the duration of pollution and range resulting from the oil-spill drift forecasting, with the shoreline sensitive resource map, that 11 segments of the shoreline may be possibly affected in total and the polluted shoreline is up to 4,625 $\mathrm{m}$ in length. ESIs for the shoreline that may be polluted include three types: 1B, 3A and 6B. Shorelines with ESI 1B refers to exposed solid man-made structures and recommended to clean up using the manual removal, pumping, high-pressure flushing etc.; Shorelines with ESI 3A are medium-sized sand beach, and recommended to clean up using manual removal, pumping, low-pressure flushing and dispersants etc.; Shoreline with ESI 6B are man-made riprap and recommended to clean up by manual removal, pumping and high-pressure flushing etc. Because the higher ESI means that the resource sensitivity is higher, it is recommended to remove pollutants on shorelines with ESI 6B in the first place.

\section{CONCLUSION AND OUTLOOK}

The paper discussed the standard classification and development of ESI as well as its application at home and abroad; made a field investigation on Shenzhen Dapeng Bay and its peripheral shorelines, and collected information concerning sensitive resources; applied the Marine Oil-spill Emergency Response Decision Support and Dispatch Command System, on the basis of high-resolution satellite images, to divide the investigated shoreline into 321 segments and defined their attribute parameters needed for ESI. 
In this paper, an oil-spill shoreline emergency response decision support process was developed and cases were studied, and functions of the Marine Oil-spill Emergency Response Decision Support and Dispatch Command System such as prediction \& warning, sensitive resources and emergency resources management were applied to intelligently produce countermeasures for ESI-based shoreline sensitive resource emergency response.

\section{ACKNOWLEDGMENT}

This paper was funded by National science and technology support programs "the Study on Integration Technology of Major Marine Oil Spill Emergency Dispatch Command" (No.2012BAC14B07) and "Safety control and emergency technology for the ship transport of dangerous goods" (No. 2015BAG20B03).

\section{REFERENCES}

[1] Michel, J., M.O. Hayes, and P.J. Brown. Application of an oil spill vulnerability index to the shoreline of lower Cook Inlet, Alaska. Environmental Geology. vol.2, pp. 107-117, 1978.

[2] NOAA, Environmental Response Management Application (ERMA) Basic User's Guide, http://response.restoration.noaa.gov, 2014-4-28

[3] Rong-Chang CHEN, Tao LI, Qian ZHAO, Study on Application of Shoreline ESI Graph in Jiaozhou Bay, China Water Transport, pp. 55-57, June 2014.

[4] Yun LI, Qian ZHAO, Yong WU, Application of Environmental Sensitive Graph in Oil-spill Emergency Plan of Zhuhai Port , Journal of Water Transportation Research Institute, pp. 52-58, March 1998.

[5] NOAA Ocean Service, Environmental Sensitivity Index Guidelines Version 3.0, NOAA Technical Memorandum NOS OR\&R 11, Seattle, Washington, 2002.

[6] Rong-Chang CHEN, Ru LAN, Development and Application of Marine Oil-spill Emergency Response Decision Support and Dispatch Command Platform, China Water Transport, Vol. 37, pp. 23-25, January 2016.

[7] Lin MOU, Qian ZHAO, Marine Oil Spill Emergency Response Technology, Science Publisher, Beijing, 2011. 